\title{
Full-Videoendoscopic Interlaminar Surgery for the Treatment of Lumbar Disc Herniations- A Series of 50 Cases
}

\section{Cirurgia totalmente videoendoscópica interlaminar para tratamento de hérnia de disco lombar-série de 50 casos}

\author{
Marco Aurélio Moscatelli Alvarenga ${ }^{1}$ Thiago Alexandre Firmo da Rocha ${ }^{1}$ Luis Marchi ${ }^{2}$ \\ Leonardo dos Santos Correia ${ }^{1}$ \\ ${ }^{1}$ Neurology and Neurosurgery Service, Neurolife, Natal, RN, Brazil. \\ Address for correspondence Marco Aurélio Moscatelli Alvarenga, \\ 2 Instituto de Patologia da Coluna, São Paulo, SP, Brazil \\ Arq Bras Neurocir 2019;38:12-19. \\ MD, Serviço de Neurologia e Neurocirurgia Neurolife, Rua São José, \\ 2.190, Lagoa Nova, Natal, RN, Brazil. CEP: 59014-430 \\ (e-mail: marcomosca13@hotmail.com).
}

\section{Abstract \\ Keywords \\ - endoscopy \\ - intervertebral disc displacement \\ - minimally invasive surgical procedures \\ - lumbar spine}

Resumo
The present study aims to describe the results of full-videoendoscopic surgery through the interlaminar route for central lumbar disc herniation in a series of 50 cases in Brazil. This is a retrospective single-center study. With the aim of describing safety, the present study reports the complication and revision rates. The clinical results were collected with the visual analogue scale (VAS) and with the Oswestry Disability Index (ODI) (a questionnaire to evaluate functional disability) at the preoperative visit and at 6 months postsurgery.

The average surgical time was 20 minutes (range: $9-40$ minutes), and $100 \%$ of the procedures were performed in an outpatient setting. The mean VAS scores improved from 9.4 to $1.1(p<0.001)$, and the mean ODI scores decreased from 69 to 9 points in the last follow-up $(p<0.001)$. There was 1 case $(2 \%)$ with hernia recurrence, 1 case with intraoperative root injury ( $2 \%$ ), and 2 cases $(4 \%)$ that required lumbar fusion due to a preexisting instability. No infections were observed.

The full-videoendoscopic surgery is a modern option for treating lumbar disc herniation. In the present study, we have observed that the use of this technique for the removal of fragments affecting the vertebral canal presented satisfactory clinical results, low complication rates, and that it has demonstrated its feasibility in an outpatient setting without prolonged hospitalization.

O objetivo do presente estudo é descrever os resultados do uso da cirurgia totalmente videoendoscópica para a retirada de hérnias centrais, utilizando a rota interlaminar em uma série de 50 casos no Brasil.

Estudo não comparativo de série de casos com análise retrospectiva de dados coletados prospectivamente em um único centro. Com o intuito de descrever a segurança, foram relatadas as complicações e também as reoperações e recidivas received

September 8, 2016

accepted

October 13, 2016
DOI https://doi.org/

$10.1055 / \mathrm{s}-0036-1596051$ ISSN $0103-5355$.
Copyright $\odot 2019$ by Thieme Revinter

Publicações Ltda, Rio de Janeiro, Brazil
License terms

ㄷ) (i) $\ominus$ (\$) 


Palavras-chave
- endoscopia
- deslocamento do
disco intervertebral
- procedimentos
cirúrgicos
minimamente
invasivos
- coluna vertebral

observadas durante o seguimento. Para a realização da análise de resultados clínicos, foram utilizados como instrumentos a escala visual analógica (EVA) e o índice Oswestry de incapacidade (ODI, na sigla em inglês) (questionário para a quantificação de incapacidade funcional) antes e 6 meses após a cirurgia.

O tempo médio de cirurgia foi de 20 minutos (entre 9 e 40 minutos), com 100\% dos pacientes tendo alta hospitalar no mesmo dia do procedimento. A média da EVA melhorou de 9,4 para $1,1(p<0,001)$, e a média do ODI caiu de 69 para 9 pontos no último acompanhamento $(p<0,001)$. Houve recidiva de hérnia em 1 caso $(2 \%), 1$ lesão intraoperatória (2\%) de raiz, e necessidade de artrodese lombar em 2 casos (4\%). Não ocorreu nenhum caso de infecção.

A cirurgia totalmente videoendoscópica é uma opção moderna para a retirada de hérnia de disco lombar. No presente trabalho, vimos que a utilização desta técnica para a retirada de fragmentos acometendo o canal vertebral gerou ótimos resultados de resolução clínica, com baixas complicações, e demonstrou ser factível em modelo ambulatorial sem internação hospitalar prolongada.

\section{Introduction}

Open discectomy procedures evolved into percutaneous microdiscectomies since the adoption of microscopy, described by Yasargil in 1967, ${ }^{1}$ and into other variations described by Hijikata et al in $1975^{2}$ and by Caspar in $1977 .^{3}$ Since then, less invasive variations in spine surgical techniques have been implemented to decrease perioperative morbidity and postoperative infections, as well as to prevent damage to adjacent tissues. In addition, these strategies have direct and measurable effects on perioperative outcomes, on mobilization, on hospitalization, on return to activities and, finally, on societal costs. ${ }^{4,5}$

Today, less invasive, endoscopic procedures are performed in central ${ }^{6,7}$ and in peripheral neurosurgery. ${ }^{8}$ Moreover, these techniques are becoming well-established in lumbar disc herniation surgery. In cases presenting with disc fragments affecting the foramen or the lateral recess, the posterolateral endoscopic procedure ${ }^{9,10}$ is performed by the transforaminal route through the Kambin triangle, or by the extraforaminal route. Cases with intracanal fragments are more challenging, and these routes are not used in them. Thus, the interlaminar route employed in full-videoendoscopic surgery has been recently described and has been used for disc herniations occupying the area of the vertebral canal. $^{11-13}$

The present study aims to describe the results of the fullvideoendoscopic surgery in the removal of central hernias using the interlaminar route in a Brazilian case series of 50 cases.

\section{Materials and Methods}

This is a non-comparative study of a case series with retrospective analysis of data prospectively collected in a single center from March 2014 to March 2016. The present study was analyzed and approved by the ethics committee of the institution in which it was conducted.

\section{Inclusion/Exclusion Criteria}

The inclusion criteria for the present study were: cases with central or centrolateral lumbar disc herniation diagnosed by magnetic resonance imaging (MRI); lack of clinical success after between 3 and 6 weeks of conservative treatment or cases evolving with acute neurological deficit; cases with symptomatology of unilateral radiculopathy; cases submitted to interlaminar, full-videoendoscopic surgery; minimum surgical follow-up of 6 months. The exclusion criteria were: cases with herniated lumbar disc in the foraminal or in the extraforaminal regions; cases treated endoscopically by the transforaminal or by the extreme lateral route; isolated lumbar pain; vertebral canal stenosis; presence of a facet cyst; discitis; cauda equina syndrome.

\section{Surgical Technique}

All of the surgical procedures were performed by the same neurosurgeon. The surgical procedure is illustrated in - Fig. 1, and the assembly of the instrumentation table is shown in $\boldsymbol{- F i g . ~} \mathbf{2}$. The procedures were performed under general anesthesia. The surgical target in the present study was the posterior portion of the intervertebral disc through the interlaminar window (-Fig. 1A-D). The interlaminar videoendoscopic technique ${ }^{11-13}$ is performed with a paramedian skin incision close to the median line, which is previously marked by fluoroscopy; then, a $6.9 \mathrm{~mm}$ diameter dilator is inserted toward the supraligamental interlaminar window (-Fig. 1E-F). After the insertion of the dilator, a $7.9 \mathrm{~mm}$ diameter working channel is placed and its bevel is directed to the ligamentum flavum; this procedure is aided by fluoroscopy (-Fig. 1G). The positioning of the endoscope through the working channel $(\mathbf{- F i g} . \mathbf{1 H})$ allows the visualization of the adjacent structures; the ligamentum flavum is opened with scissors, using the beveled work channel to retract the adjacent neural structures under direct endoscopic vision. The endoscopic view with $6.9 \times 5.6 \mathrm{~mm}$ optics, $165 \mathrm{~mm}$ length and $25^{\circ}$ angulation (-Fig. 1I) allows the 


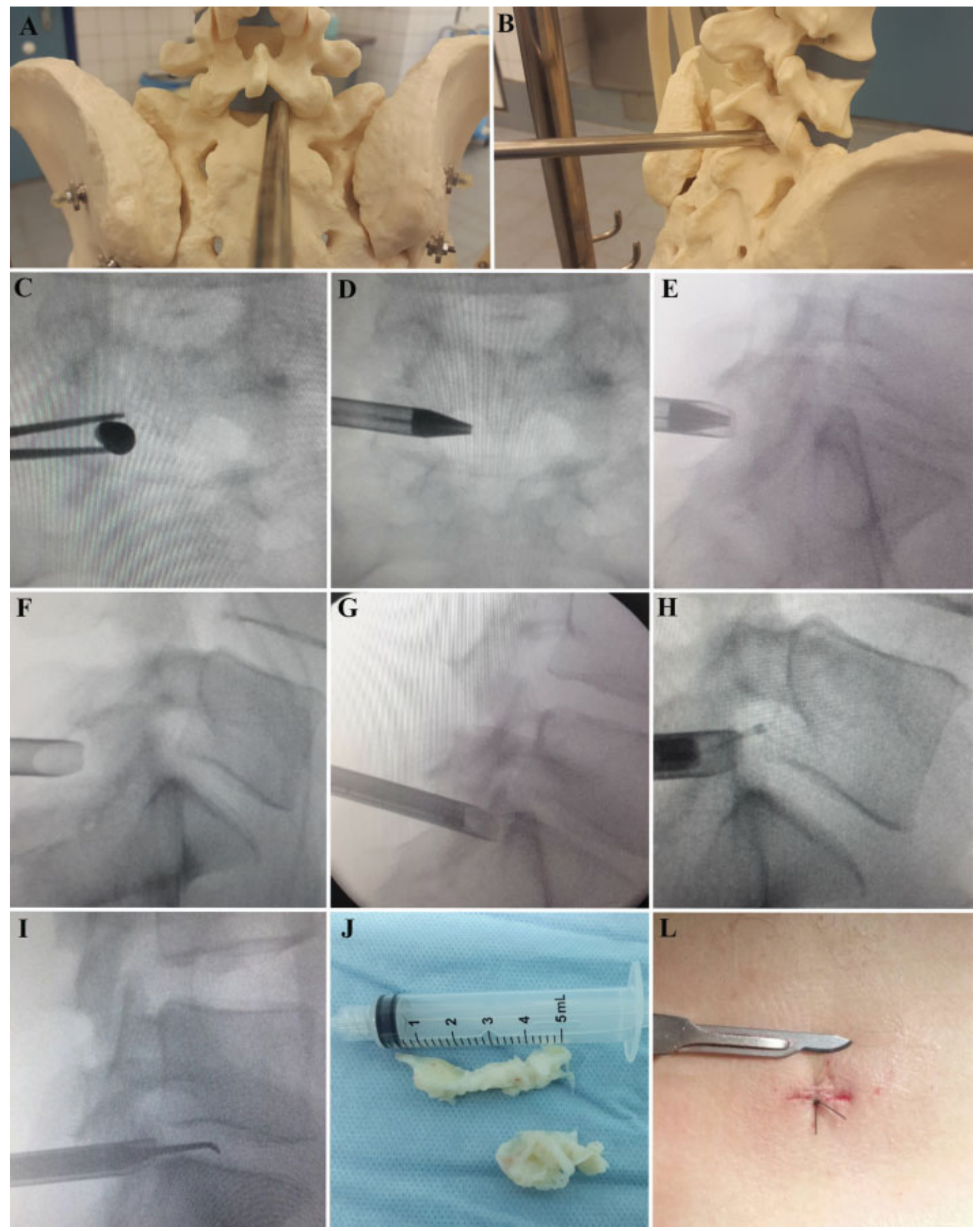

Fig. 1 Full-videoendoscopic surgical procedure through the interlaminar route. An anatomical model exemplifies (A) the anteroposterior view and $(B)$ the lateral view. The surgical procedure is controlled by fluoroscopy for (C-E) localization, (F) interlaminar route access, ( $\mathrm{G}$ and $\mathrm{H})$ channel access, and ( $I$ and $J$ ) the removal of disc fragments. (L) The surgical incision is closed with a skin suture.

detailed observation of the structural intimate relationship (between the herniated fragment, the bulgings, the root of the nerve, and of the joint and the lamina of the facet). The use of appropriate materials, such as dissector, disc clamp, punch, and radiofrequency bipolar cautery, allows the performance of the procedure with greater safety. The intervertebral disc herniated fragment(s) is (are) removed (-Fig. 1J), and the procedure is finalized with rigorous hemostasis, local steroid placement, and skin suture using nylon 3.0 (-Fig. 1L). In order to avoid infections, the following protocol is used: cefuroxime $2 \mathrm{~g}$ intravenously during the anesthetic induction and cephalexin at a therapeutic dose for 7 days postoperatively.

The surgery described above is planned with a day hospital protocol, without the need for an overnight stay. In this protocol, the patient is admitted 3 hours before the 


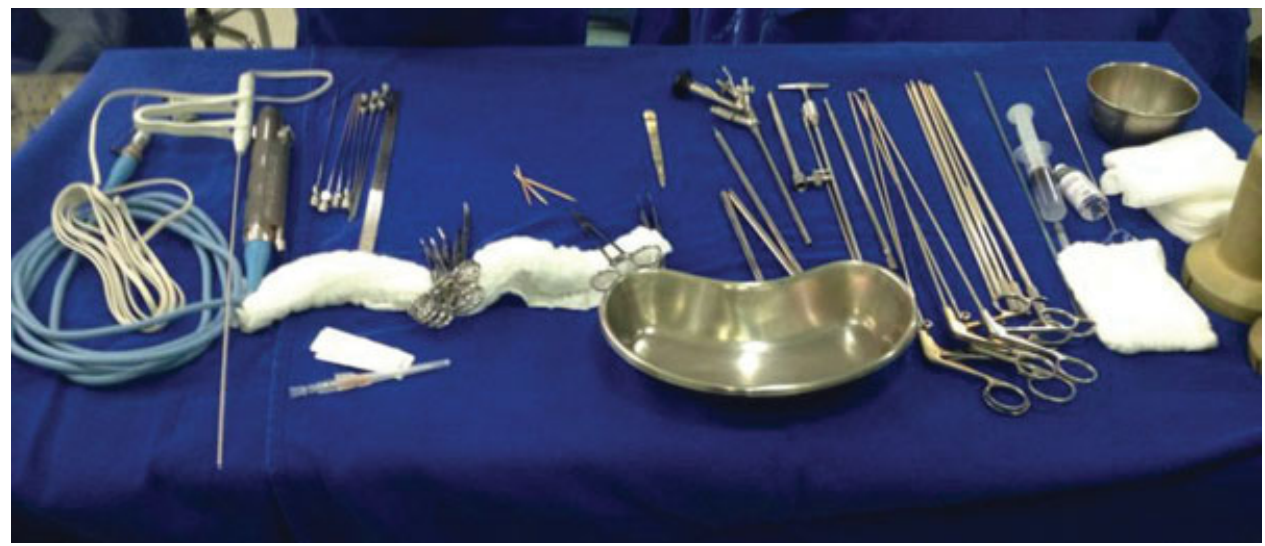

Fig. 2 Exemplification of the surgical materials used and of the configuration of the instrument table.

procedure and is discharged after 3 hours of postanesthetic observation, on the same day of the procedure.

\section{Analyzed Outcomes}

Data were collected before the surgery, intraoperatively, and 6 months after the procedure. Intraoperative and postoperative complications, as well as revision surgeries, were recorded.

The following instruments were used to analyze the clinical improvement after the surgery: the visual analogue scale $^{14}$ (VAS) for lumbar and irradiated pain (for pain assessment) and the Oswestry Disability Index ${ }^{15}$ (ODI) (for functional disability assessment). The patients completed these questionnaires before the procedure and 6 months postsurgery.

\section{Statistical Analysis}

The data were submitted to a qualitative and quantitative descriptive analysis and to a comparative statistical analysis. The statistical tests were performed with SPSS Statistics for Windows, Version 10.0 (SPSS Inc., Chicago, IL, USA) using $\alpha$ values of 0.05 . The two-tailed paired Student $t$-test was performed.

\section{Results}

\section{Study Group}

From a total of 123 patients submitted to videoendoscopic surgery at the spinal surgery center, 73 were cases treated through the posterolateral or the extraforaminal routes. The present study analyzed 50 cases that met the inclusion and exclusion criteria. - Table 1 shows the demographic data of the group. From the 50 selected patients, $20(40 \%)$ were female, and 30 (60\%) were male, with ages ranging from 19 to 69 years old, with a mean age of 32.4 years old. Regarding lumbar disc involvement, 1 (2\%) was at the L3-L4 lumbar level; 23 cases (46\%), L4-L5; and 26 (52\%), L5-S1. The clinical picture lasted from 2 days to 13 months.

\section{Surgical Results}

Surgery data are shown in -Table $\mathbf{2}$. The mean time for the surgical procedure was 20 minutes (9-40 minutes). There
Table 1 Demographic data

\begin{tabular}{|l|l|}
\hline Total cases & $\mathbf{5 0}$ \\
\hline Female & $20(40 \%)$ \\
\hline Male & $30(60 \%)$ \\
\hline Age (years old) & $32.4(19-69)$ \\
\hline $\begin{array}{l}\text { Time with preoperative } \\
\text { symptoms (months) }\end{array}$ & $8(2-13)$ \\
\hline L3-L4 lumbar level & $1(2 \%)$ \\
\hline L4-L5 lumbar level & $23(46 \%)$ \\
\hline L5-S1 lumbar level & $26(52 \%)$ \\
\hline
\end{tabular}

was no significant blood loss in any case, and, thus, there was no need for blood transfusion. There was no inadvertent durotomy during the analyzed procedures. With a single suture at the surgical incisions, no overnight hospitalization was required, and the median hospital stay was 3 hours.

\section{Clinical Improvement}

Pain and physical disability levels, determined respectively by the VAS and ODI scales, were compared before and after the surgery (6 months after the procedure). In the pain scale, an improvement of $88 \%$ was observed at 6 months, with a statistically significant reduction from the original average score of 9.4 to $1.1(p<0.001)$ ( - Fig. 3). Physical disability

Table 2 Surgical and postoperative data

\begin{tabular}{|l|l|}
\hline Surgical time (minutes) & $20(9-40)$ \\
\hline Durotomy & $0(0 \%)$ \\
\hline Intraoperative lesion in L5 & $1(2 \%)$ \\
\hline Infection & $0(0 \%)$ \\
\hline Hospitalization (hours) & $3(2.5-4)$ \\
\hline Herniation recurrence & $1(2 \%)$ \\
\hline Review (arthrodesis) & $2(4 \%)$ \\
\hline
\end{tabular}




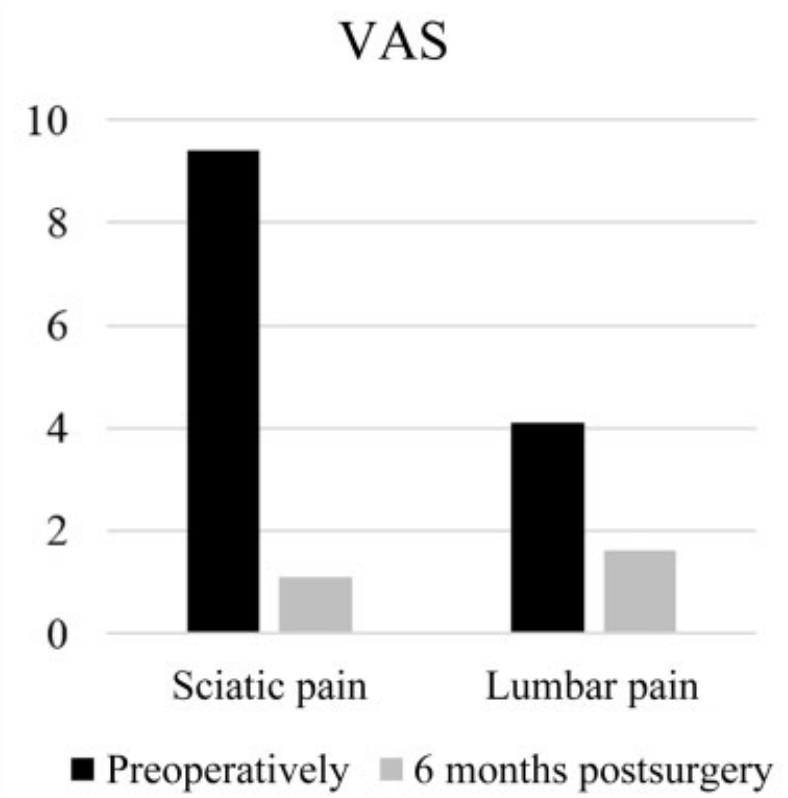

Fig. 3 Mean pain assessed by the visual analogue scale (VAS) in the studied group before the procedure and 6 months postsurgery $(p<0.001)$.

showed an $87 \%$ decrease, from 69 to 9 points in the final follow-up ( $p<0.001)$ ( -Fig. 4). An exemplificative case is shown in - Fig. 5 .

\section{Complications and Reoperations}

Complication and reoperation data are compiled in - Table 2 . One recurrence case occurred in this period (2\%). Another case (2\%) presented an intraoperative L5 root lesion. Lumbar arthrodesis was required in 2 cases ( $4 \% ; 1$ case at the L4-L5 lumbar level, and 1 case at the L5-S1 lumbar level) 6 months postvideoendoscopy, due to a previous instability with discal decay and, consequently, to a foraminal stenosis with sciatica. There were no cases of postoperative deep or superficial infection.

\section{Discussion}

Lumbar disc herniation generating pain that irradiates to the lower limbs and is refractory to conservative treatment requires removal by the decompression of the neural structures, either of the isolated nerve root or of the dural sac. ${ }^{16}$ Disc herniation surgery evolved from open discectomy procedures to microdiscectomy, and then to videoendoscopic discectomy. This evolution aims to reduce the surgical aggression to the surrounding tissues, but without altering the surgical objective, which is the release of nervous compression. When the resection of the surrounding structures is avoided or decreased, the less traumatic disc removal can reduce the collateral damage caused by the surgery. $^{17-19}$

The full-videoendoscopic surgery is performed by a single portal, using an endoscope with an intraendoscopic working channel. ${ }^{12}$ The technique has been successfully used, achiev-

\section{ODI}

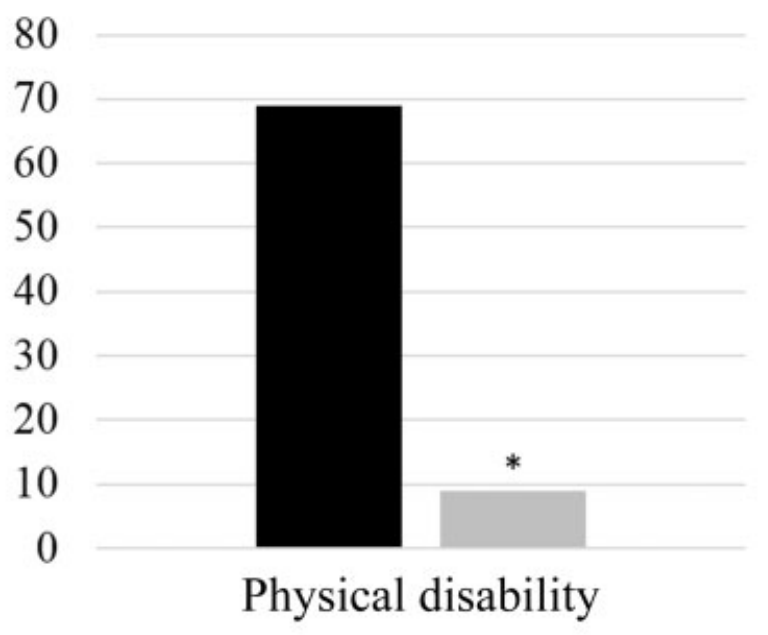

- Preoperatively $\quad 6$ months postsurgery

Fig. 4 Mean of the physical inactivity score measured by the Oswestry disability index (ODI) in the studied group before the procedure and 6 months postsurgery ${ }^{*} p<0.001$.

ing the same goals of microdiscectomy, but also reducing perioperative local pain and surgical complications. ${ }^{20-23}$ The transforaminal or the posterolateral routes are widely employed, but they present technical limitations, such as in cases with fragments located in the vertebral canal. ${ }^{24}$ Thus, the interlaminar technique was developed to allow the removal of hernias that are not accessible through the transforaminal technique. ${ }^{11,12}$ The present study is, in the knowledge of the authors, the first work in Portuguese to describe the results of this surgical option.

The final clinical results of the full-videoendoscopic procedure and of the surgical microdiscectomy have been very similar in some clinical trials regarding the reoperation index and the clinical improvement. ${ }^{25,26}$ However, the advantages of the full-videoendoscopic surgery are highlighted. The adoption of these techniques improved low back pain, post-surgical rehabilitation, intraoperative complications, and tissue trauma. ${ }^{25}$ The main implication is the possibility of carrying out the procedure with safety, even in patients with comorbidities and who demand a quick return to daily activities, because, compared with microdiscectomy, the incision is smaller, the blood loss is negligible, there is less damage to the paraspinal musculature, and the patient may be discharged earlier and already walking. For the surgeon, access is easy in obese and morbidly obese patients, and the visualization of structures is better due to the absence of blood and to the closer proximity using optics with saline irrigation.

Comparative clinical trials showed that microdiscectomy and the full-videoendoscopic technique yield very similar results regarding medium- and long-term resolution of the pain caused by neural compression, ${ }^{25,27,28}$ with an improvement ranging from 75 to $90 \%$ in VAS scores, and from 67 to 

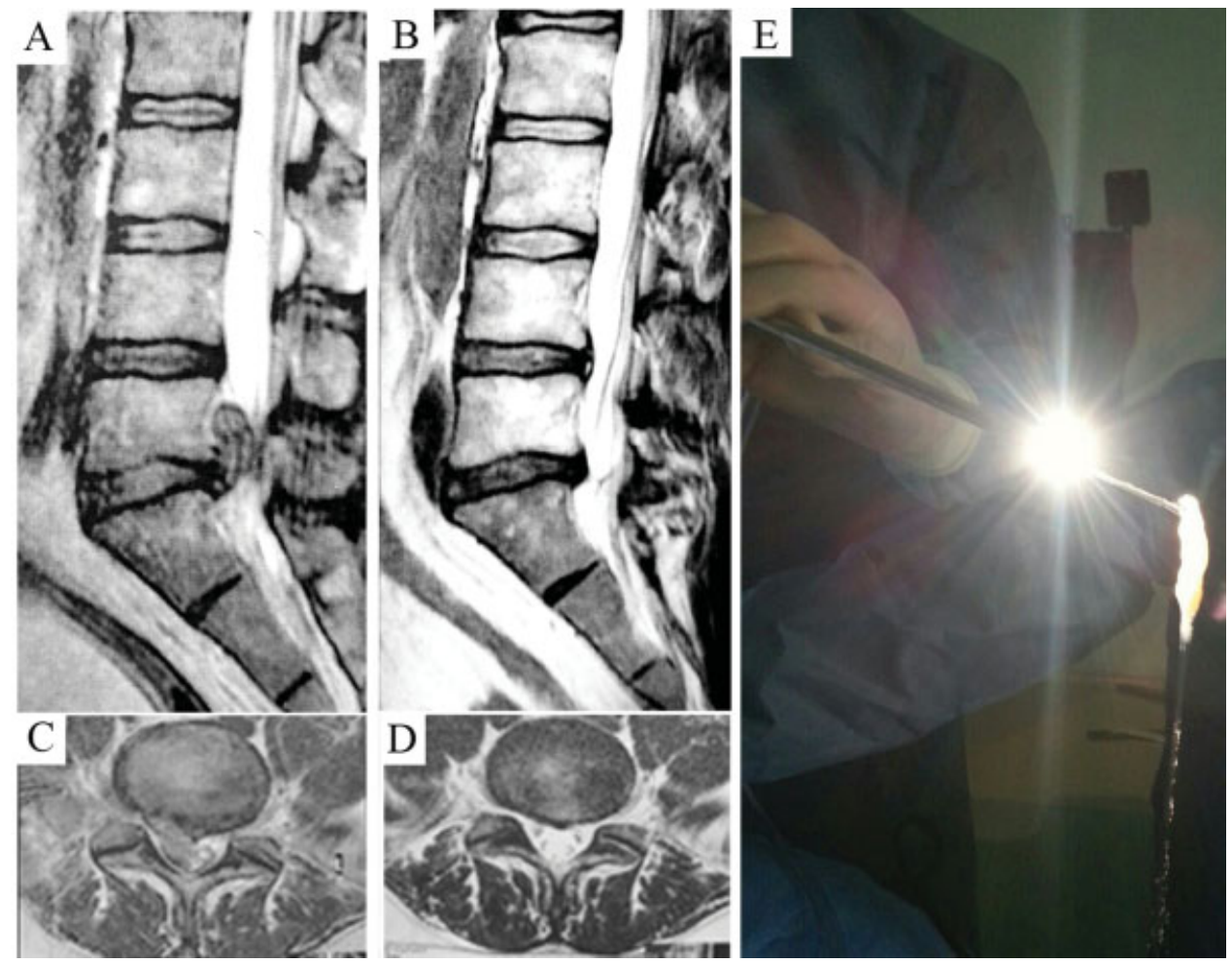

Fig. 5 Magnetic resonance images of the lumbar spine during the preoperative period in (A) sagittal section and in (B) axial section, and in the postoperative period in (C) sagittal section and in (D) axial section. Note the presence of a bulky fragment in the preoperative images, which was removed during the surgery $(\mathrm{E})$, and the resulting decompression of the vertebral canal and the maintenance of bone and muscular integrity in the postoperative images.

$80 \%$ in physical disability measured by the ODI. In the present case series, we have observed an improvement of $88 \%$ in VAS pain scores, and an $87 \%$ decrease in the physical restriction determined by the ODI questionnaire.

Consistently, an analysis of $>100$ thousand surgeries confirmed that less invasive approaches are associated with lower infection rates after lumbar discectomy. ${ }^{29}$ The general intraoperative complication rate in less invasive discectomy is very low, totaling $\sim 1.6 \%$, and it includes infection, re-herniation, neurological deficit, incisional hematoma, cerebrospinal fluid (CSF) fistula, pulmonary embolism, and acute myocardial infarction. ${ }^{30}$ Remnant fragments are the main cause of procedural failure. Recurrence is a considerable event in these procedures, with results ranging from 4.2 to $12.5 \%$, with an average value of $6 \%$ ( $2 \%$ in the present study), depending on the duration of the follow-up in each analysis. ${ }^{25,27,28,31}$ Moreover, there is no difference in the hernia recurrence rate between microdiscectomy and the full-videoendoscopic technique. No durotomy was observed in our case series, which is in line with the literature, in which the average rate of non-intentional intraoperative durotomy ranges from 0 to $3 \%$, with no statistical difference between the 2 techniques, which is also explained by its low incidence. $^{25,27,28}$ Severe complications were noted in 4 of the 50 cases in the present study ( 1 intraoperative neural injury, 1 recurrence, and 2 evolutions for an indication for arthrodesis). It was previously observed that non-severe complications are significantly higher in groups treated with microdiscectomy than in those submitted to the full-videoendoscopic technique. $^{17-19}$

The main difference in complications among the two techniques is the lowest possibility of infection with the endoscopy, since it is performed with continuous irrigation. In the present study, there was no superficial or deep infection. The studied group routinely uses an extended 7-day therapeutic protocol with cephalexin, which is unusual, but cited in other studies, in order to reduce the incidence of infection (1.7\% versus $4.3 \%){ }^{32}$ However, this subject still requires larger, controlled studies comparing different protocols. ${ }^{33}$ Despite heterogeneous reports among papers, the hospitalization time for microdiscectomy ranges from 1 to 7 days, ${ }^{16,27,28,31,34,35}$ exceeding the time for less invasive surgeries, such as sequestrectomy and full-videoendoscopic discectomy, which can be performed in an outpatient setting, ${ }^{13,27,36}$ without overnight stay and bed occupancy.

In summary, a meta-analysis on microdiscectomy and on the full-videoendoscopic technique shows that both options are very efficient for the surgical objective, but none has a broad superiority regarding clinical outcomes, complications or reoperations. However, the full-videoendoscopic technique has a shorter hospitalization time (outpatient procedure) and a shorter operative time. ${ }^{37}$ Thus, it should be noted that a reduced hospitalization time means, in addition to less discomfort and greater satisfaction for the patient, a reduction of costs and demands to the health system, bringing 
benefits to the society, as has already been observed in costbenefit studies performed in other countries. ${ }^{38-41}$

\section{Conclusion}

The full-endoscopic surgery for lumbar disc herniation involving the spinal canal led to a satisfactory clinical resolution with a low complication rate; moreover, it was deemed feasible for an outpatient model without prolonged hospitalization.

\section{Conflicts of Interest}

The authors have no conflicts of interest to declare.

\section{References}

1 Yasargil MG. Microsurgical Operation of Herniated Lumbar Disc. In: Wüllenweber R, Brock M, Hamer J, Klinger M, Spoerri $O$, organizadorers. Lumbar Disc Adult Hydrocephalus [Internet]. Springer Berlin Heidelberg; 1977 [citado 30 de agosto de 2016]. p. 81-81. (Advances in Neurosurgery). Disponível em: http://link. springer.com/chapter/10.1007/978-3-642-66578-3_16

2 Hijikata S, Yamagishi M, Nakayama T, Oomori K. Percutaneous nucleotomy. A new treatment method for lumbar disc herniation. J Toden Hosp. 1975;5:39-44

3 Castro Id, Santos DP, Christoph DH, Landeiro JA. The history of spinal surgery for disc disease: an illustrated timeline. Arq Neuropsiquiatr 2005;63(3A):701-706

4 McAfee PC, Phillips FM, Andersson G, et al. Minimally invasive spine surgery. Spine 2010;35(26, Suppl)S271-S273

5 McAfee PC, Garfin SR, Rodgers WB, Allen RT, Phillips F, Kim C. An attempt at clinically defining and assessing minimally invasive surgery compared with traditional "open" spinal surgery. SAS J 2011;5(04):125-130

6 Biasi P, Roso L, Manfroi G, et al. Chiari IV Malformation, the Lückenschädel and Sagittal Craniosynostosis Association: Case Report and Literature Review. Arq Bras Neurocir. 2015;35(01): $74-77$

7 Giannetti A, Guimarães R, Crosara P. Acesso transesfenoidal aos adenomas hipofisários: do microscópio ao endoscópio. Arq Bras Neurocir Braz Neurosurg [Internet]. 29 de março de 2016 [citado 31 de agosto de 2016]; Disponível em: http://www.thieme-connect.de/DOI/DOI?10.1055/s-0036-1580737

8 Magalhães M, Ferreira V. Síndrome compressiva de múltiplos nervos na dermatopolimiosite: relato de caso. Arq Bras Neurocir. 2016;35(01):85-88

9 Yeung AT, Tsou PM. Posterolateral endoscopic excision for lumbar disc herniation: Surgical technique, outcome, and complications in 307 consecutive cases. Spine 2002;27(07):722-731

10 García CM. Endoscopia lumbar póstero lateral con sistema YESS: reporte preliminar. Coluna/Columna 2009;8(02):192-196

11 Ruetten S. The Full-endoscopic Interlaminar Approach for Lumbar Disc Herniations. In: M.D HMM, organizador. Minimally Invasive Spine Surgery [Internet]. Springer Berlin Heidelberg; 2006 [citado 30 de agosto de 2016]. p. 346-55. Disponível em: http://link.springer.com/chapter/10.1007/3540-29490-2_38

12 Ruetten S, Komp M, Godolias G. Full-endoscopic interlaminar operation of lumbar disc herniations using new endoscopes and instruments. Orthop Prax 2005;10:527-532

13 Alvarenga MAM, Vargas AAR, de Lima MSX, Kallef PR. Descrição da técnica cirúrgica minimamente invasiva vídeo totalmente endoscópica interlaminar para tratamento de hérnia de disco lombar. Arq Bras Neurocir. 2014;33(03):202-206
14 Downie WW, Leatham PA, Rhind VM, Wright V, Branco JA, Anderson JA. Studies with pain rating scales. Ann Rheum Dis 1978;37(04):378-381

15 Vigatto R, Alexandre NM, Correa Filho HR. Development of a Brazilian Portuguese version of the Oswestry Disability Index: cross-cultural adaptation, reliability, and validity. Spine 2007;32 (04):481-486

16 SBOT, SBN. Hérnia de Disco Lombar no Adulto: Tratamento Cirúrgico. Diretrizes Clínicas Na Saúde Supl AMB ANSS. 2011;1-8.

17 Kotilainen E, Valtonen S. Clinical instability of the lumbar spine after microdiscectomy. Acta Neurochir (Wien) 1993;125(14):120-126

18 Johnsson KE, Redlund-Johnell I, Udén A, Willner S. Preoperative and postoperative instability in lumbar spinal stenosis. Spine 1989;14(06):591-593

19 Zander T, Rohlmann A, Klöckner C, Bergmann G. Influence of graded facetectomy and laminectomy on spinal biomechanics. Eur Spine J 2003;12(04):427-434

20 Choi G, Lee SH, Raiturker PP, Lee S, Chae YS. Percutaneous endoscopic interlaminar discectomy for intracanalicular disc herniations at L5-S1 using a rigid working channel endoscope. Neurosurgery 2006;58(1, Suppl):ONS59-ONS68, discussion ONS59-ONS68

21 Faulhauer K, Manicke C. Fragment excision versus conventional disc removal in the microsurgical treatment of herniated lumbar disc. Acta Neurochir (Wien) 1995;133(3-4):107-111

22 Balderston RA, Gilyard GG, Jones AA, et al. The treatment of lumbar disc herniation: simple fragment excision versus disc space curettage. J Spinal Disord 1991;4(01):22-25

23 Türeyen K. One-level one-sided lumbar disc surgery with and without microscopic assistance: 1-year outcome in 114 consecutive patients. J Neurosurg 2003;99(3, Suppl) 247-250

24 Ruetten S, Komp M, Godolias G. An extreme lateral access for the surgery of lumbar disc herniations inside the spinal canal using the full-endoscopic uniportal transforaminal approach-technique and prospective results of 463 patients. Spine 2005;30(22): 2570-2578

25 Ruetten S, Komp M, Merk H, Godolias G. Full-endoscopic interlaminar and transforaminal lumbar discectomy versus conventional microsurgical technique: a prospective, randomized, controlled study. Spine 2008;33(09):931-939

26 Ruetten S, Komp M, Merk H, Godolias G. Recurrent lumbar disc herniation after conventional discectomy: a prospective, randomized study comparing full-endoscopic interlaminar and transforaminal versus microsurgical revision. J Spinal Disord Tech 2009;22(02):122-129

27 Righesso O, Falavigna A, Avanzi O. Comparison of open discectomy with microendoscopic discectomy in lumbar disc herniations: results of a randomized controlled trial. Neurosurgery 2007;61 (03):545-549, discussion 549

28 Majeed SA, Vikraman CS, Mathew V, S AT. . Comparison of outcomes between conventional lumbar fenestration discectomy and minimally invasive lumbar discectomy: an observational study with a minimum 2-year follow-up. J Orthop Surg Res 2013;8:34

29 Smith JS, Shaffrey CI, Sansur CA, et al; Scoliosis Research Society Morbidity and Mortality Committee. Rates of infection after spine surgery based on 108,419 procedures: a report from the Scoliosis Research Society Morbidity and Mortality Committee. Spine 2011;36(07):556-563

30 Ramirez LF, Thisted R. Complications and demographic characteristics of patients undergoing lumbar discectomy in community hospitals. Neurosurgery 1989;25(02):226-230, discussion 230-231

31 Davis RA. A long-term outcome analysis of 984 surgically treated herniated lumbar discs. J Neurosurg 1994;80(03):415-421 
32 Hellbusch LC, Helzer-Julin M, Doran SE, et al. Single-dose vs multiple-dose antibiotic prophylaxis in instrumented lumbar fusion-a prospective study. Surg Neurol 2008;70(06):622-627, discussion 627

33 Shaffer WO, Baisden J, Fernand R, Matz PG. Antibiotic Prophylaxis in Spine Surgery. In: Evidence-Based Clinical Guidelines for Multidisciplinary Spine Care. NASS Evidence-Based Clinical Guidelines Committee; 2013

34 Weinstein JN, Lurie JD, Tosteson TD, et al. Surgical versus nonoperative treatment for lumbar disc herniation: four-year results for the Spine Patient Outcomes Research Trial (SPORT). Spine 2008;33(25):2789-2800

35 Huang T, Tian Z, Li M, et al. Sequestrectomy versus microdiscectomy in the treatment of lumbar disc herniation: a meta-analysis. Int J Clin Exp Med 2015;8(05):7261-7269

36 Choi G, Lee SH, Nicolau RJ. Discectomia endoscópica percutânea lombar (DELP). Coluna/Columna 2008;7(02):177-182
37 Ruan W, Feng F, Liu Z, Xie J, Cai L, Ping A. Comparison of percutaneous endoscopic lumbar discectomy versus open lumbar microdiscectomy for lumbar disc herniation: A meta-analysis. Int J Surg 2016;31:86-92

38 Allen RT, Garfin SR. The economics of minimally invasive spine surgery: the value perspective. Spine 2010;35(26, Suppl): S375-S382

39 Anderson DG, Wang P. Value analysis of minimally invasive spine surgery. Semin Spine Surg 2014;26(01):52-55

40 Deluzio KJ, Lucio JC, Rodgers WB. Value and cost in less invasive spinal fusion surgery: lessons from a community hospital. SAS J 2010;4(02):37-40

41 Lucio JC, Vanconia RB, Deluzio KJ, Lehmen JA, Rodgers JA, Rodgers W. Economics of less invasive spinal surgery: an analysis of hospital cost differences between open and minimally invasive instrumented spinal fusion procedures during the perioperative period. Risk Manag Healthc Policy 2012;5:65-74 